\title{
In Vitro Myelosuppression and
}

\section{Immunosuppression by Ethanol}

\author{
Glenn Tisman and Victor Herbert \\ From the Department of Medicine, Bronx Veterans Administration Hospital, \\ New York 10468, and the Department of Pathology, Columbia University \\ College of Physicians and Surgeons, New York 10032
}

A B S T R A C T Concentrations of ethanol similar to those in the blood of intoxicated patients suppressed phytohemagglutinin- or streptolysin O-induced lymphocyte transformation, and inhibited bone marrow granulocyte colony growth in soft agar. Inhibition of lymphocyte transformation and granulocyte colony growth occurred despite the presence of large concentrations of folate and other vitamins. These in vitro findings may relate to in vivo effects of ethanol on myeloid and lymphoid tissue.

\section{INTRODUCTION}

Preliminary studies suggested that ethanol might have a toxic effect in vitro on human bone marrow cells and lymphocytes (1-3). The current findings extend that preliminary information, using concentrations of ethanol such as may occur in heavily intoxicated alcoholic individuals.

\section{METHODS}

Subjects. Blood and bone marrow specimens were obtained from patients on the general medical and hematology wards. The patients studied included individuals with diabetes mellitus, alcoholism, infection, or neoplasm, plus normal volunteers. None of the patients were receiving myelosuppressive therapy.

Lymphocyte collection and culture. Heparinized blood specimens (collected in $60-\mathrm{ml}$ syringes containing heparin, $0.75 \mathrm{mg}$ heparin $/ \mathrm{ml}$ blood) were allowed to sediment in the original syringe placed nozzle up at a $45^{\circ}$ angle at room temperature for $2 \mathrm{~h}$. The leukocyte-rich plasma was then expressed through a Butterfly-19 infusion tube (Butterfly-19 infusion set, 4590, Abbott Scientific Products Div., Abbott Laboratories, South Pasadena, Calif.), by pressing the plunger of the syringe, into a $500 \mathrm{ml}$ sterile bottle containing an equal volume of culture medium; the solution was then percolated through a sterile absorbent cotton

Dr. Herbert is a Career Scientist from the Health Research Council of the City of New York and holds a Medical Investigatorship from the Veterans Administration.

Received for publication 21 November 1972 and in revised form 26 January 1973.
(Acme Cotton Products Co., Inc., Valley Stream, N. Y.) or a Fenwal FT-242 scrubbed nylon fiber column (Fenwal Inc., Walter Kidde \& Co. Inc., Ashland, Mass.) $12 \times 1.4$ $\mathrm{cm}$, loosely packed, at $37^{\circ} \mathrm{C}$. The yield of lymphocytes was between 25 and $50 \%$ with a lymphocyte purity of $80-90 \%$, and $95 \%$ viability as measured by trypan blue dye exclusion. The eluted lymphocytes were washed once with $10-\mathrm{ml}$ portions of the medium employed for that experiment. The washed lymphocytes were then cultured in $16 \times 125-\mathrm{mm}$ Falcon (Falcon Plastics, Oxnard, Calif.) plastic tubes $\left(10^{\circ}\right.$ cells $/ \mathrm{ml}$ ) in $3 \mathrm{ml}$ of $\mathrm{pH} 7.4,0.06 \mathrm{M}$ Tris-buffered Hanks balanced salt solution (containing $200 \mathrm{U} / \mathrm{ml}$ each of penicillin and streptomycin), a solution of 20 amino acids (4) plus $13 \mathrm{mg}$ L-serine and $28 \mathrm{mg}$ glycine/liter, plus $200 \mathrm{mM} /$ liter L-glutamine (THAA), ${ }^{1}$ plus $10 \%$ autologous serum or fetal calf serum. Alternatively, incubation was in RPMI 1640 (Roswell Park Memorial Institute 1640 incubation medium, purchased from Microbiological Associates, Inc., Bethesda, Md.) $+200 \mathrm{mM} /$ liter L-glutamine $+200 \mathrm{U} / \mathrm{ml}$ of penicillin and streptomycin containing $10 \%$ serum. Difco phytohemagglutinin-P (PHA-P) (Difco Laboratories, Detroit, Mich.) was reconstituted with $5 \mathrm{ml}$ THAA and 0.1 $\mathrm{ml}$ of the product was added to each tube except for PHA-P controls. Streptolysin O (SLO) (Hyland Div., Travenol Laboratories, Inc., Costa Mesa, Calif.) was reconstituted with $10 \mathrm{ml}$ THAA, and $0.1 \mathrm{ml}$ was added to each culture. Ethanol (alcohol, dehydrated analyzed reagent, U. S. Industrial Chemicals Co., Tuscola, Ill.) in varying concentrations was added to cultures which were then incubated at $37^{\circ} \mathrm{C}$ for 3 days, in a 7.5\% $\mathrm{CO}_{2}-92.5 \%$ air incubator, which maintained $\mathrm{pH}$ unchanged, after which $0.1 \mathrm{ml}$ tritiated thymidine ( ${ }^{3} \mathrm{HTdR}$ ), $10 \mu \mathrm{Ci} / \mathrm{ml}$ (sp act $=26 \mathrm{Ci} / \mathrm{mM}$; Amersham/Searle Corp., Arlington Heights, Ill.) was added, and incubation continued for another $4 \mathrm{~h}$. The cells were then transferred to glass tubes, centrifuged at $1500 \mathrm{rpm}$ for $10 \mathrm{~min}$, and the supernate discarded. $2 \mathrm{ml}$ of the $10 \%$ cold $\left(4^{\circ} \mathrm{C}\right)$ trichloroacetic acid (TCA) was added to the cell pellet, and the acid insoluble precipitate dissolved in $0.5 \mathrm{ml}$ of hydroxide of hyamine (Packard Instrument Co., Inc., Downers Grove, Ill.) plus $15 \mathrm{ml}$ of liquid scintillation fluid (2,5-diphenyloxazole [PPO, $17.5 \mathrm{~g}]+1,4$-bis [2-(5phenyloxazolyl)] benzene [POPOP, $1.5 \mathrm{~g}$ ] (Packard Instru-

${ }^{1}$ Abbreviations used in this paper: ${ }^{3} \mathrm{HTdR}$, tritiated thymidine; $\mathrm{M} / \mathrm{E}$, myeloid/erythroid ratio; $\mathrm{PGA}$, pteroylglutamic acid; PHA-P, phytohemagglutinin; SLO, streptolysin O ; THBSS, Tris-buffered Hanks-balanced salt solution; THAA, THBSS plus 20 added amino acids. 
ment Co., Inc.) $+875 \mathrm{ml}$ ethanol $+2,626 \mathrm{ml}$ toluene [Fisher Scientific Co., Inc., Pittsburgh, Pa.]) and counted in a Beckman LS-250 refrigerated liquid scintillation counter (Beckman Instruments, Inc., Fullerton, Calif.).

Morphologic evidence of mitogen-induced lymphocyte transformation was obtained by microscopic examination. Study of 3-day incubated cells, both in the presence and absence of ethanol, revealed no apparent toxicity due to presence of ethanol. Trypan blue studies after PHA-P were difficult to interpret due to clumping. However, there was no apparent difference between control cells and cells cultured in the presence of ethanol (concn. $=300 \mathrm{mg} / 100 \mathrm{ml}$ ).

Short-term bone marrow culture. The techniques employed were essentially those previously used in this laboratory $(5,6) \cdot 10-20 \mathrm{ml}$ of bone marrow (of which most, after the 1st $\mathrm{ml}$, was peripheral blood) was aspirated from the posterior superior iliac spine into a syringe containing

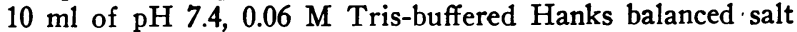
solution containing $200 \mathrm{U} / \mathrm{ml}$ each of penicillin and streptomycin (THBSS) plus $100 \mathrm{mg}$ of heparin. The cells were passed through a 50 mesh, 0.003 in. gauge wire screen and washed with a $10 \mathrm{ml}$ portion of THBSS. The cells were then suspended in autologous serum-enriched (25\%) THBSS and $0.3-\mathrm{ml}$ portions added to $10-\mathrm{ml}$ B-D Vacutainer tubes (Becton-Dickinson \& Co., Rutherford, N. J.). Cell count ranged between 2 and $12 \times 10^{\circ} / \mathrm{ml}$ of final culture. $0.1-\mathrm{ml}$ portions of varying concentrations of ethanol were added, and the final volume adjusted to $0.9 \mathrm{ml}$ with THBSS. After $1 \mathrm{~h}$ incubation in a Dubnoff metabolic-shaker incubator at $37^{\circ} \mathrm{C}, 0.1 \mathrm{ml}$ of ${ }^{8} \mathrm{HTdR}(10 \mu \mathrm{Ci} / \mathrm{ml}$, sp act $=$ $25 \mathrm{Ci} / \mathrm{mM}$ ) was added and incubation continued for 3 more $h$. After incubation the cells were washed in THBSS and then shock-lysed to remove hemoglobin (7). TCA at $3^{\circ} \mathrm{C}$ was added as in lymphocyte cultures and the radioactivity of the acid-insoluble material determined, as an index of incorporation of ${ }^{8} \mathrm{HTdR}$ into DNA.

Bone marrow culture in soft agar. The technique here employed using bone marrow cells is essentially that used by Kurnick and Robinson (8) for culture of peripheral blood cells. $5-10 \mathrm{ml}$ of bone marrow is aspirated into a heparin-wet syringe. Red cells were allowed to sediment in the original syringe standing on its plunger at room temperature for $2 \mathrm{~h}$. The cell-rich plasma was then expressed and centrifuged, and the cells were washed three times in $10-\mathrm{ml}$ portions of McCoys 5A medium. Peripheral blood drawn at the same time was similarly allowed to sediment. The leukocyte-rich plasma was separated and its cells used as a source of colony-stimulating factor, as had been done by Kurnick and Robinson (8). To $35-\mathrm{mm}$ tissue culture dishes (Falcon Plastics) is added $1 \mathrm{ml}$ underlayer containing $10^{6}$ peripheral leukocytes, suspended in $0.5 \%$ agar in McCoys $5 \mathrm{~A}$ medium with $15 \%$ fetal calf serum. After gelling, a 1 $\mathrm{ml}$ overlay containing 200,000 washed bone marrow cells, 0.3 agar and McCoys 5A medium plus $15 \%$ fetal calf serum was poured over the underlayer. Before gelling, ethanol in varying concentrations was added to the overlay; after gelling, the plates were incubated in a $100 \%$ humidity, $7.5 \%$ $\mathrm{CO}_{2}-92.5 \%$ air atmosphere for 10-14 days, which maintained $\mathrm{pH}$ unchanged. (Agar was prevented from drying out by placing the plates in a larger covered petri dish which contained a $35 \mathrm{~mm}$ uncovered water-containing dish.) Only colonies containing more than 50 cells were counted by use of a stereo microscope at 30 times magnification. In general, colonies consisted of both early and late granulocytes and macrophages. Many mitotic forms were present, and cell/colony varied between 50 and 1,500 .

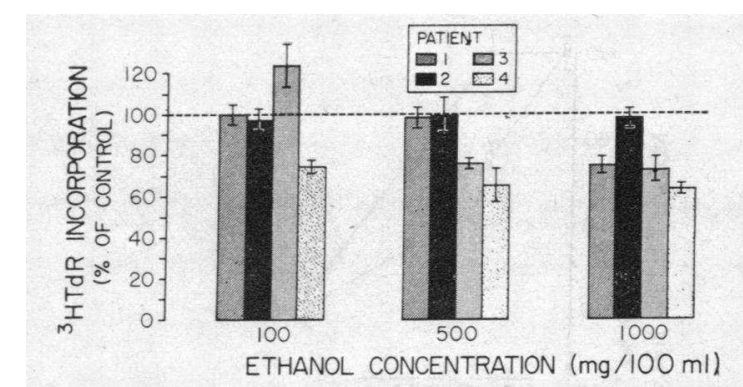

FIGURE 1 Effect of various concentrations of ethanol on incorporation of ${ }^{3} \mathrm{HTdR}$ into bone marrow DNA. Vertical lines $= \pm 1 \mathrm{SD}$. Diagnosis: patients 1 and 2, iron deficiency anemia ; 3 , rheumatoid arthritis, patient 4 , diabetes mellitus.

\section{RESULTS}

Experiments employing short-term ( $4 \mathrm{~h}$ ) bone marrow cultures demonstrated significant ethanol inhibition of ${ }^{3} \mathrm{HTdR}$ incorporation into DNA only with large concentrations of ethanol (Fig. 1) (Controls ranged from 3-4 $\times 10^{3} \mathrm{cpm} / 10^{6}$ cells). Bone marrow morphology from patients 1-4 varied only in the myeloid to erythroid $(\mathrm{M} / \mathrm{E})$ ratio: Patients 1 and 2 had $\mathrm{M} / \mathrm{E}$ ratios of $1: 1$ and $1: 2$, patients 3 and 4 had $M / E$ ratios of $6: 1$ and $4: 1$.

Colony growth in soft agar. Bone marrow colony growth in soft agar was sharply inhibited by concentrations of ethanol which are present in intoxicated patients. Fig. 2 reveals effects on colony count in the presence of ethanol. The addition of folinic acid (leucovorin, citrovorum factor $)(10 \mu \mathrm{g} / \mathrm{ml})$ to the already folatecontaining McCoys 5A medium (McCoys 5A medium contains $10 \mathrm{mg} /$ liter of pteroylglutamic acid [PGA]) did not reverse ethanol inhibition of colony growth (not shown in Figure). At the time colony counts were done, all colonies of any one patient consisted of either granulocytes alone or contained both granulocyte and macrophage elements.

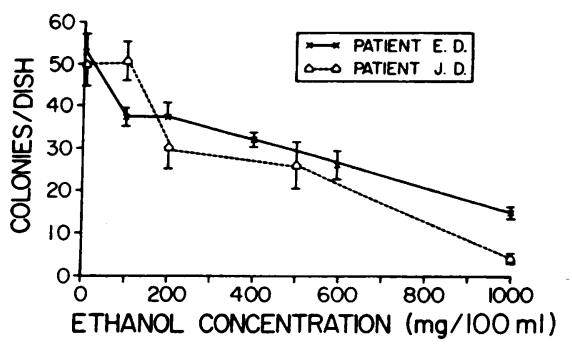

Figure 2 Inhibition by various concentrations of ethanol of bone marrow colony growth in soft agar of two different patients from noted in Fig. 1. Diagnosis: patient E. D., pancreatic carcinoma; patient J. D., diabetes mellitus. Underlay leukocytes were from each patient studied. Colony counts are the average of three dishes. Vertical lines= $\pm 1 \mathrm{SD}$. 


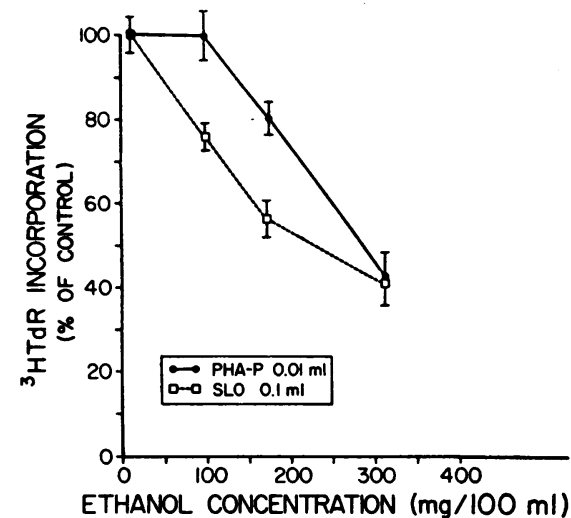

FIGURE 3 Ethanol inhibition of SLO- and PHA-P-induced lymphocyte transformation as measured by incorporation of ${ }^{8} \mathrm{HTdR}$ into lymphocyte DNA. Patient had diabetes mellitus. Culture medium was THAA plus $10 \%$ autologous serum. Vertical lines $= \pm 1 \mathrm{SD}$.

Ethanol inhibition of lymphocyte transformation. Lymphocyte transformation response to PHA-P and SLO was markedly inhibited by ethanol (Fig. 3). (Control $\mathrm{cpm} / 10^{8}$ cells $=20 \times 10^{3}$ for $\mathrm{PHA}-\mathrm{P}$ and $5 \times 10^{3}$ for SLO.)

Fig. 4 reveals lymphocyte response in counts per minute $(\mathrm{cpm})$ of ${ }^{3} \mathrm{HTdR}$ incorporated into lymphocyte DNA at the end of $72 \mathrm{~h}$. Note that ethanol was found again to be a potent inhibitor of lymphocyte transformation. Lymphocyte transformation using PGA-enriched medium (RPMI 1640 contains $1 \mathrm{mg} /$ liter of PGA) was also inhibited by ethanol (Fig. 5).

Inhibition of granulocyte colony growth and of lymphocyte transformation was not overcome by adding to

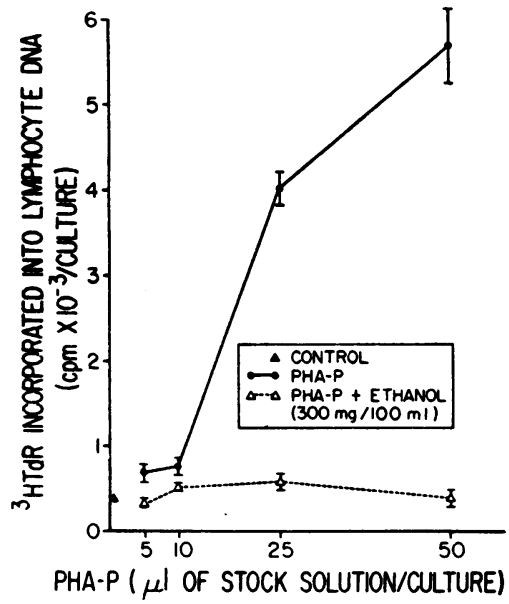

FIGURE 4 Ethanol inhibition of lymphocyte transformation induced by varying concentrations of PHA-P. Normal volunteer. Culture medium was RPMI 1640 plus $200 \mathrm{mM} /$ liter L-glutamine plus $0.06 \mathrm{M}$ Tris buffer $\mathrm{pH} 7.4$, plus $10 \%$ fetal calf serum. Vertical lines $= \pm 1 \mathrm{SD}$.

1412 each milliliter of the incubation medium $10 \mu \mathrm{g}$ of PGA, $2 \mu \mathrm{g}$ of $\mathrm{B}_{12}, 0.5 \mu \mathrm{g}$ pyridoxal $\mathrm{HCl}$, and $0.5 \mu \mathrm{g}$ pyridoxine $\mathrm{HCl}$. The alcohol effect was not observed using isosmotic amounts of glucose.

\section{DISCUSSION}

Alcohol ingestion has been associated with a number of hematologic disabilities (9-11) including anemia, thrombopenia, and leukopenia. The causes of anemia appear to be multifactorial including protein-calorie malnutrition, folate, $\mathrm{B}_{8}$, and iron deficiency, liver disease and lipemia, and perhaps a direct toxic effect of ethanol on folate metabolism. Thrombopenia and leukopenia are usually attributed to splenomegaly secondary to portal hypertension or concomitant folate deficiency. Leukopenia in alcoholics without splenomegaly, significant liver disease or folate deficiency has suggested a direct toxic effect of ethanol on myelopoiesis $(9,10)$.

The alcoholic patient is susceptible to infection (12, 13). Contributing factors may include luekopenia, and the alcoholic's life style, i.e., "Bowery living." Guarneri and Laurenzi (13) have reported that ethanol has a toxic effect on pulmonary macrophage function. It is not known whether alcohol or one of its metabolites is the toxic agent. Since the monocyte and pulmonary macrophage have recently been reported to be sources of colony-stimulating factor (14-16), one posible ethanol effect may be to reduce the production of this factor by the leukocyte-rich underlayer of our bone marrow cultures in soft agar.

"Bone marrow culture on soft agar" as described by Kurnick and Robinson (8) is a good and sensitive technique for the study of myelopoiesis. The validity of using this technique for the study of the suppressive effect of drugs or other chemicals on myelopoiesis has also been demonstrated by Ogawa, Bergsagel, and $\mathrm{McCulloch}$ $(21,22)$.

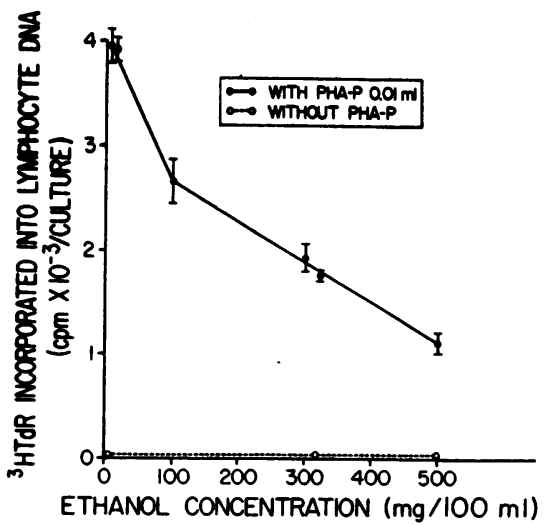

Figure 5 Ethanol inhibition of PHA-P-induced lymphocyte transformation. Culture medium was THAA plus $10 \%$ autologous serum. Normal volunteer. Vertical lines $= \pm 1 \mathrm{SD}$. 
The in vitro data here presented suggest that alcohol may suppress immunocompetence and inhibit myeloid tissue growth when the alcohol is present in concentrations present in the blood of chronic alcoholics, and that this suppression may not be overcome by enriching the incubation medium with up to $10 \mu \mathrm{g}$ of folic acid $/ \mathrm{ml}, 2$ $\mu \mathrm{g} \mathrm{B}_{12} / \mathrm{ml}$, and $0.5 \mu \mathrm{g}$ pyridoxal $\mathrm{HCl} / \mathrm{ml}$. The question arises as to why the effects observed in vitro are not also rapidly observed in vivo. The answer may lie in part in the fact that the in vitro effects are observed after days of continuous exposure to the stated concentrations of alcohol. In vivo, such concentrations are rarely sustained over any continuous $24 \mathrm{~h}$ period.

$\mathrm{T}$ and $\mathrm{B}$ lymphocytes cooperate to express cellular and humoral immunity $(17,18)$. The inhibition of phytohemagglutinin-induced lymphocyte transformation here noted suggests that primarily $\mathrm{T}$-cell function is depressed by ethanol ingestion.

In the current studies, suppressive effects on myeloid and lymphoid function occurred with in vitro concentrations of ethanol in the range of $200-300 \mathrm{mg} / 100 \mathrm{ml}$; such concentrations may occur in heavily intoxicated individuals. It should be noted that under the proposed national Uniform Act Regulating Traffic on Highways, the presence of $150 \mathrm{mg}$ or more of ethanol $100 \mathrm{ml}$ blood is the minimum standard for presuming drunkenness from blood ethanol evidence (19).

Colonies contained granulocytes alone, or both granulocytes and macrophages. Perturbation by ethanol of the normal proportions of each was not found. Therefore, it is possible that ethanol may inhibit macrophage as well as granulocyte production. Since macrophages may be involved in antigen processing (20), this, too, might contribute to suppression of immunocompetence in vitro.

The three in vitro effects of alcohol (inhibition of lymphocyte transformation, and inhibition of macrophage and granulocyte production) are all directed against immune defense. Whether they relate to susceptibility to infection present in vivo in chronic alcoholic patients, remains to be determined, as does the mechanism of the alcohol effect in vitro. The data presented here can be attacked on the grounds that the demonstrated myelosuppressive effect may be nonspecific, since decreased colony growth can be observed with a number of chemical compounds, some of which exhibit concentrationdependent suppression. However, alcohol is unlike these other compounds in that it is present in the intoxicated human body in concentrations such as here used in vitro. Furthermore, Ogawa et al. $(21,22)$ have recently reported that a system essentially identical to the Kurnick and Robinson (8) in vitro technique used in the current study is valid for the study of the suppressive effect of chemical compounds on myelopoiesis, in that it was capable of predicting drug response in vivo.
The fact that the concentrations of alcohol here used in vitro were similar to those present in vivo in intoxicated individuals does not rule out the possibility that the observed alcohol effect was nonspecific, but does suggest that even should the effect prove to be nonspecific (i.e., an osmotic or $\mathrm{pH}$ effect, for example), it would pertain in vivo as well as in vitro when there is similarity of alcohol concentration in both systems. Against osmotic effect as the explanation is the report that osmotic effect may actually enhance lymphocyte growth (23), and that isosmotic amounts of glucose were not inhibitory in the current study. Against $\mathrm{pH}$ effect is the fact that there was no measurable $\mathrm{pH}$ change in the medium during incubations.

It should be noted that there is also evidence supporting a toxic ethanol effect producing thrombocytopenia $(24,25)$.

\section{ACKNOWLEDGMENTS}

We are indebted to Misses Le Teng Go and Lois Brenner for expert technical assistance.

This work was supported in part by U. S. Public Health Service grant AM15163, by Career Scientist Award I-683 from the Health Research Council of the City of New York, and by a Medical Investigatorship from the Veterans Administration to Dr. Herbert.

\section{REFERENCES}

1. Corcino, J., S. Waxman, A. Rubin, and V. Herbert. 1970. Selective suppression by ethanol of RNA synthesis in human hematopoietic cells in vitro: fact or artefact? J. Clin. Invest. 49: 22a. (Abstr.)

2. Tisman, G., V. Herbert, L. T. Go, and L. Brenner. 1971. In vitro demonstration of immunosuppression without bone marrow suppression by alcohol and bleomycin. Clin. Res. 19: 730.

3. Tisman, G., V. Herbert, L. T. Go, and L. Brenner. 1972. Alcohol and infection: suppression by ethanol of human myelopoiesis. Am. J. Clin. Nutr. 25: 460.

4. Daughaday, W. H., and M. L. Parker. 1963. Sulfation factor measurement as an aid in the recognition of pituitary dwarfism. J. Clin. Endocrinol. Metab. 23: 638.

5. Metz, J., A. Kelly, V. C. Swett, S. Waxman, and V. Herbert. 1968. Deranged DNA synthesis of bone marrow from vitamin $\mathrm{B}_{18}$-deficient humans. Br. J. Haematol. $14: 575$.

6. Tisman, G., V. Herbert, L. T. Go, and L. Brenner. 1972. Inhibition by penicillamine of DNA and protein synthesis by human bone marrow. Proc. Soc. Exp. Biol. Med. $139: 355$.

7. Corcino, J., S. Krauss, S. Waxman, and V. Herbert. 1970. Release of vitamin $B_{12}$ binding protein by human leukocytes in vitro. J. Clin. Invest. 49: 2250.

8. Kurnick, J. E., and W. A. Robinson. 1971. Colony growth of human peripheral white blood cells in vitro. Blood. $37: 136$.

9. McFarland, W., and E. P. Libre. 1963. Abnormal leukocyte response in alcoholism. Ann. Intern. Med. 59: 865.

10. Liu, Y. K. 1972. Leukopenia in alcoholics. Clin. Res. 20: 78. 
11. Sullivan, L. W., and V. Herbert. 1964. Suppression of hematopoiesis by ethanol. J. Clin. Invest. 43: 2048.

12. Brayton, R. G., P. Stokes, and D. B. Louria. 1965. The effects of alcohol on host defenses. J. Clin. Invest. 44: 1030.

13. Guarneri, J. J., and G. A. Laurenzi. 1968. Effect of alcohol on the mobilization of alveolar macrophages. J. Lab. Clin. Med. 72: 40.

14. Golde, D. W., and M. J. Cline. 1972. Identification of the colony-stimulating cell in human peripheral blood. J. Clin. Invest. 51 : 2981.

15. Chervenick, P. A., and A. F. LoBuglio. 1972. Human blood monocytes: stimulation of granulocyte and mononuclear colony formation in vitro. Science (Wash. D. C.). $178: 164$.

16. Golde, D. W., T. N. Finley, and M. J. Cline. 1972. Production of colony-stimulating factor by human macrophages. Lancet. 2 : 1397.

17. Playfair, J. H. L. 1972. Response of mouse $T$ and $B$ lymphocytes to sheep erythrocytes. Nat. New Biol. 235: 115.

18. Tridente, G., G. Biasi, L. Chieco-Bianchi, and L. FioreDonati. 1971. Thymus-marrow cell interaction evaluated by PHA stimulation and graft vs. host activity. Nature (Lond.). 234 : 105.
19. Maguire, J. M., J. B. Weinstein, J. H. Chadbourn, and J. H. Mansfield. 1965. Cases and Materials on Evidence. The Foundation Press, Inc., Mineola, N. Y. 731.

20. Rubin, A. S., and A. H. Coons. 1972. Specific heterologous enhancement of immune response. II. Immunological memory cells of thymic origin. J. Exp. Med. $135: 437$.

21. Ogawa, M., D. E. Bergsagel, and E. A. McCulloch. 1973. Chemotherapy of mouse myeloma: quantitative cell cultures predictive of response in vivo. Blood. 41: 7.

22. Ogawa, M., D. E. Bergsagel, and E. A. McCulloch. 1971. Differential effects of melphalan on mouse myeloma (AdJ. PC-5) and hemopoietic stem cells. Cancer Res. 31 : 2116.

23. Moscona, A., O. A. Trowell, and E. N. Willmer. 1965. In Cells and Tissues in Culture: Methods, Biology, Physiology. E. Willmer, editor. Academic Press, Inc., New York. 23.

24. Sullivan, L. W., Y. K. Liu, L. Talarico, and C. P. Emerson. 1968. Alcohol-induced thrombocytopenia in man. J. Clin. Invest. 47: 95a. (Abstr.)

25. Lindenbaum, J., and R. L. Hargrove. 1968. Thrombocytopenia in alcoholics. Ann. Intern. Med. 68: 526. 